\title{
Plant Regeneration Through Nodal Explant Derived Callus in Wood Apple (Aegle marmelos L.)
}

\author{
Ranjoy Das ${ }^{\mathrm{a}}$, M. Faruk Hasan ${ }^{\mathrm{a}}$, Harunar Rashid ${ }^{\mathrm{b}}$ and Motiur Rahman ${ }^{\mathrm{b} *}$ \\ ${ }^{a}$ Department of Genetic Engineering and Biotechnology, and ${ }^{b}$ Department of Botany, University of Rajshahi, \\ Rajshahi-6205, Bangladesh.
}

\begin{abstract}
This study reports on an improved protocol for callus induction and subsequent regeneration from nodal segment of wood apple (Aegle marmelos L.) Creamish friable competent callus was achieved from nodal segments on MS medium augmented with $4.0 \mathrm{mg}^{-1}$ 2,4-D within two weeks of inoculation. The callus produced large number of shoots when cultured on MS medium fortified with $2.0 \mathrm{mgl}^{-1} \mathrm{BAP}+0.1 \mathrm{mgl}^{-1} \mathrm{NAA}$ within ten days of culture. In vitro raised shoots were rooted on half strength MS medium enriched with $1.0 \mathrm{mgl}^{-1}$ IBA within fifteen days of culture. The rooted plantlets were successfully established with $80 \%$ survival.
\end{abstract}

Key words: Plant regeneration, Callus induction, Nodal explant, Aegle marmelos.

\section{Introduction}

Wood apple (Aegle marmelos L.) is an improtant tree species with multiple utility belonging to the family Rutaceae. In Bangladesh this plant is known as "Bael Tree". It is indigenous to Indian subcontinent and mostly found in Tropical and subtropical region (Purohit and Vyas 2005). It is medium sized tree having profuse dimorphic branched, alternate, trifoliate, deep green leaves; membranous leaflets; large, sweet scented, greenish white flowers; large, oblong or globose fruits (Purohit and Vyas 2005). The plant has the capacity to adapt successfully to a wide range of habitats from arid, semi arid, xerophytic to mesophytic soil (Arya et al. 1981). Almost all parts of the tree are used in preparing herbal medicine (Kala 2006). The unripe fruit is an astringent, a digestive and stomachic, and is used to cure diarrhea and dysentery (Watt 1889); the ripe fruit is used for curing dyspepsia (Jauhari et al. 1969), anaemia, asthma, jaundice, diarrhea, and typhoid (Paricha 2004). The roots and bark are used in the treatment of diarrhea, fever (Mazumder et al. 2006), and to control pain in the abdomen (Kirtikar and Basu 1935). The leaves are used in the treatment of diabetes (Narendhirakannan et al. 2005), snakebites (Purohit and Vyas 2005) and cause abortion and sterility in women (Morton 1987). The leaf possesses pesticidal (Singh and Roy 1984) anti-inflammatory and analgesic properties (Arul et al.
2005). Its flower is said to be alexiphanmic (Purohit and Vyas 2005). The seed have anti microbial activity (Purohit and Vyas 2005) and pesticidal properties (Singh and Roy 1984). Also, the tree yields quality timber for making pestles, posts, Shafts, and furniture (Ajithkumar and Seeni 1998).

There is wide genetic variability in terms of quality, form, and size of the fruit (Bhati et al. 1992). Also, seeds have short viability and are prone to insect and fungal attack (Purohit and Vyas 2005). Although vegetative propagation through root suckers is possible, the number of propagules produced through this technique is very limited. Alternatively, in vitro micropropagation techniques offer opportunities for multiplying disease-free planting material in a larger quantity within a short span of time. In recent years, there have been few reports on micropropagation of Aegle marmelos using different explants (Arumugam and Rao 1996; Ajithkumar and Seeni 1998). However, so far our knowledge goes, there is no report on the establishment of a micropopagation protocol for Aegle marmelos using nodal explants in Bangladesh. The present investigation demonstrates an effective high frequency regeneration method for producing a large number of plants from nodal explants of Aegle marmelos.

\footnotetext{
* Corresponding author: E-mail: motiur7@yahoo.com
} 


\section{Materials and Methods}

Seeds from mature fruits of Aegle marmelos were collected from Rajshahi University campus, Bangladesh. The seeds were washed thoroughly in running tap water for 30 minutes and then soaked in Tween-80 and Savlon for 10 minutes. Then the seeds were washed in distilled water for several times. Finally, the seeds were rinsed in $0.1 \% \mathrm{HgCl}_{2}$ for 10 minute and washed with autoclaved distilled water for several times to remove the traces of sterilant. Then, the sterilized seeds were inoculated to sterile seed germinating medium (MS) in culture bottle. Nodal segments were excised from two week old in vitro grown seedlings and inoculated onto MS medium (Murashige and Skoog 1962) fortified with different concentrations and combinations of auxin and cytokinin.

Throughout the experiments, both full strength MS medium and half strength MS medium with 3\% (W/V) sucrose and gelled with $0.8 \%(\mathrm{~W} / \mathrm{V})$ agar was used. In all cases, the $\mathrm{pH}$ of the medium was adjusted to 5.7 before autoclaving and adding agar. About $10 \mathrm{ml}$ of the medium were dispensed in each culture tube and sealed with nonabsorbent cotton plugs prior to autoclaving at $121^{\mathrm{O}} \mathrm{C}$ for 21 minutes. The cultures were incubated in a culture room at $25 \pm 2{ }^{\mathrm{O}} \mathrm{C}$ with a photoperiod of 16 hour at 3000 lux light intensity provided by cool white fluorescent tubes. In this investigation, the basal medium was supplemented with different concentrations of auxin for callus induction. Once the callus developed, they were further cultured for regeneration and elongation in the medium having different concentrations and combinations of auxin and cytokinin. Elongated shoots were rooted on half strength MS medium supplemented with different concentrations of auxin (IBA) singly. After 35 days, well rooted plantlets were obtained. Subsequently, the plantlets were removed from the culture vessels, washed gently under running tap water and planted in pots containing sterile sand, soil and humus in the ratio of 1:2:2 (Fig. F). The potted plantlets were covered by polythene sheet to maintain suitable humidity. After sufficient acclimatization, the plantlets were transplanted in the field condition, where $80 \%$ plants were survived.

\section{Results and Discussion}

\section{Callus induction}

For callus induction, nodal segments were cultured on MS medium supplemented with different concentrations of 2,4-
D (1.0-6.0 $\mathrm{mgl}^{-1}$ ). Callus induction was observed within ten to nineteen days of culture from the cut surface of the nodal explants. The highest percentage of callus induction from nodal explants was $72.22 \%$ onto the medium fortified with $4.0 \mathrm{mgl}^{-1}$ 2,4-D (Fig. A, Table I) followed by $61.11 \%$ on the medium having $3.0 \mathrm{mgl}^{-1}$ 2,4-D. On the other hand the lowest percentage of callus induction was $11.11 \%$ on MS medium augmented with $1.0 \mathrm{mgl}^{-1}$ 2,4-D. In these treatments the induced calli were creamish in color and structurally nodular. Similar results were reported in several plants including, Ceropegia candelabrum (Beena and Martin 2003), Ocimum sanctum L. (Singh and Sehgal 1999), G entiana spp (Fiuk and Rybczynski 2008), Azadirachta indica (Quraishi et al. 2004).

Table I. Effect of different concentrations of 2, 4-D in MS medium on callus induction.

\begin{tabular}{l|c|c|c}
\hline $\begin{array}{l}\text { Growth } \\
\text { regulators } \\
\left(\mathrm{mgl}^{-1}\right) \\
2,4-\mathrm{D}\end{array}$ & $\begin{array}{c}\text { Days to callus } \\
\text { initiation }\end{array}$ & $\begin{array}{c}\text { \%of explants } \\
\text { producing callus }\end{array}$ & $\begin{array}{c}\text { Nature of } \\
\text { callus }\end{array}$ \\
\hline 1 & $11-17$ & 11.11 & Creamish \\
2 & $11-18$ & 50.00 & Creamish \\
3 & $10-17$ & 61.11 & Creamish \\
4 & $11-19$ & $72.22 *$ & Creamish \\
5 & $10-17$ & 40.21 & Creamish \\
6 & $10-18$ & 33.33 & Creamish \\
\hline
\end{tabular}

Note : Each value represents an average of 10 replicates and each experiment was repeated at least thrice. $*=$ Highest response

\section{Shoot regeneration}

For shoot regeneration, the nodal segment derived calli were sub cultured in MS medium supplemented with different combinations and concentrations of BAP (1.0-2.0 $\left.\mathrm{mgl}^{-1}\right)$ and NAA (0.1-1.0 $\mathrm{mgl}^{-1}$ ). According to the tabulated data (Table II), the highest percentage of shoot induction was $90 \%$ on the medium enriched with $2.0 \mathrm{mgl}^{-1} \mathrm{BAP}+0.1 \mathrm{mgl}^{-1} \mathrm{NAA}$.

The highest number of shoots per callus was 9.0£1.0 in MS medium supplemented with $2.0 \mathrm{mgl}^{-1} \mathrm{BAP} \pm 0.1 \mathrm{mgl}^{-1} \mathrm{NAA}$ followed by $7.0 \pm 1.0$ in MS medium having $1.0 \mathrm{mgl}^{-1}$ $\mathrm{BAP} \pm 0.1 \mathrm{mgl}^{-1} \mathrm{NAA}$. On the contrary, the lowest percentage of shoot induction was $20.08 \%$ in the medium fortified with 

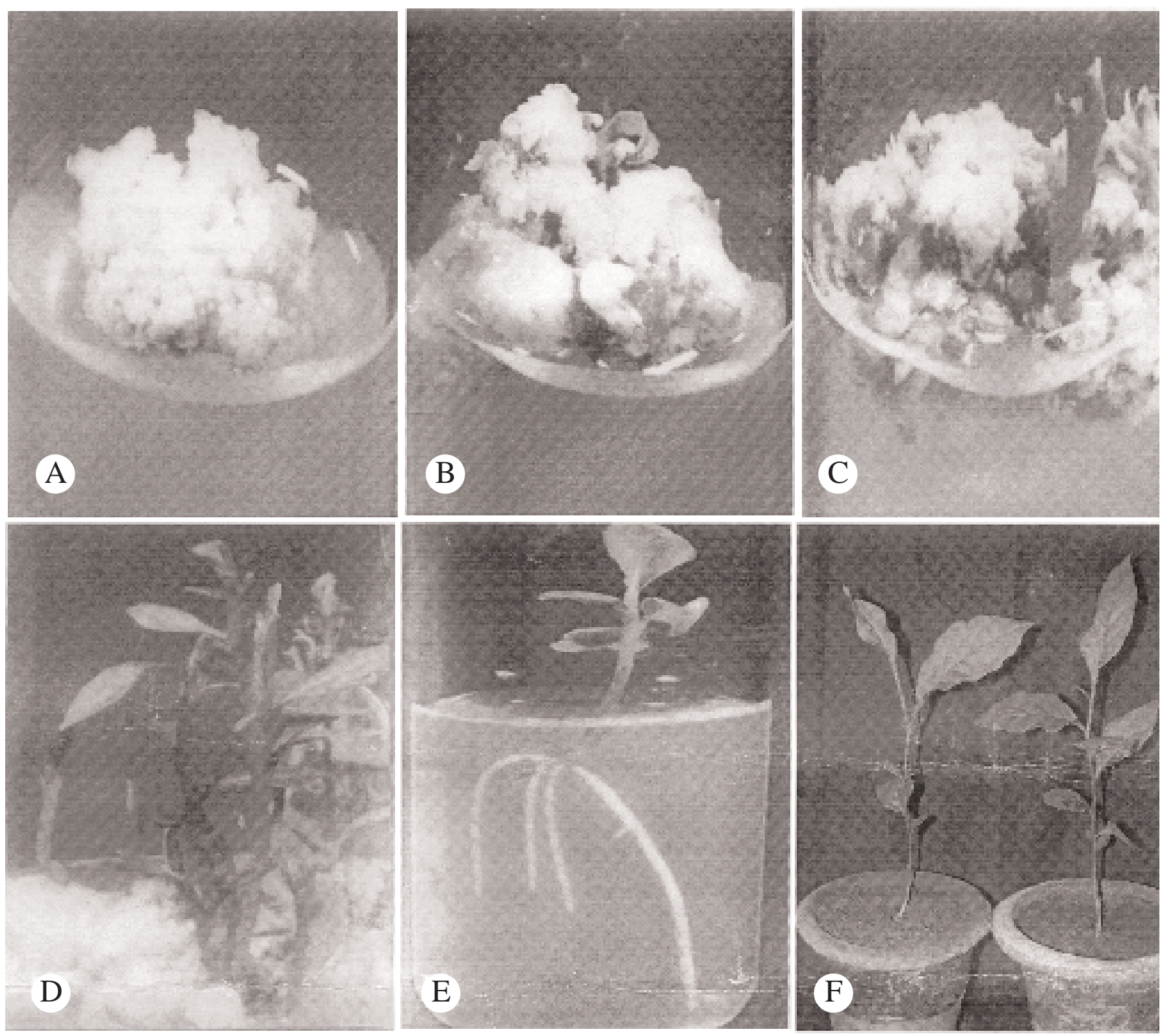

Fig. Callus induction and plant regeneration from nodal explants of Aegle marmelos

A. Callus initiation on MS having $4.0 \mathrm{mgl}^{-1}$ 2,4-D.

B-C. Shoot formation from callus on MS with $2.0 \mathrm{mgl}^{-1} \mathrm{BAP}+0.1 \mathrm{mgl}^{-1} \mathrm{NAA}$.

D. Elongation of shoots on MS having $2.0 \mathrm{mgl}^{-1} \mathrm{BAP}+0.1 \mathrm{mgl}^{-1} \mathrm{NAA}$.

E. Induction of roots on regenerated shoots on half strength MS with $1.0 \mathrm{mgl}^{-1}$ IBA.

F. Hardening of well developed plantlets. 
$1.0 \mathrm{mgl}^{-1} \mathrm{BAP}+1.0 \mathrm{mgl}^{-1} \mathrm{NAA}$ and the lowest number of shoot induction was $3.0 \pm 1.0$ in the medium having 1.0 $\mathrm{mgl}^{-1} \mathrm{BAP}+1.0 \mathrm{mgl}^{-1} \mathrm{NAA}$. Thus $2.0 \mathrm{mgl}^{-1} \mathrm{BAP}+0.1 \mathrm{mgl}^{-1}$ NAA was found to be an ideal treatment for shoot induction as well as elongation (Fig. D). Such type of plant regeneration was also reported in several medicinal plant species including, Carica papaya (Islam et al. 2000),

Table II. Effect of different combinations of BAP and NAA in MS medium for shoot regeneration.

\begin{tabular}{|c|c|c|c|c|}
\hline \multicolumn{2}{|c|}{$\begin{array}{l}\text { Growth } \\
\text { regulators } \\
\left(\mathrm{mgl}^{-1}\right) \\
\text { BAP+NAA }\end{array}$} & $\begin{array}{c}\% \text { of callus } \\
\text { derived } \\
\text { shoots }\end{array}$ & $\begin{array}{c}\text { Mean No. of } \\
\text { shoots/callus } \\
(\mathrm{M} \pm \mathrm{SE})\end{array}$ & $\begin{array}{l}\text { Length of } \\
\text { shoots } \\
(\mathrm{cm}) \\
(\mathrm{M}+\mathrm{SE})\end{array}$ \\
\hline \multirow{3}{*}{1.0} & 0.1 & 88.24 & $7.0 \pm 1.0$ & $5.3 \pm 0.3$ \\
\hline & 0.5 & 58.83 & $4.5 \pm 0.5$ & $5.4 \pm 0.6$ \\
\hline & 1.0 & 20.08 & $3.0+1.0$ & $4.6+1.0$ \\
\hline \multirow{3}{*}{2.0} & 0.1 & $90.00 *$ & $9.0 \pm 1.0$ & $5.8 \pm 0.8$ \\
\hline & 0.5 & 75.52 & $6.0 \pm 1.0$ & $5.5 \pm 0.5$ \\
\hline & 1.0 & 52.95 & $4.0 \pm 0.5$ & $3.5 \pm 0.8$ \\
\hline
\end{tabular}

Note : Each value represents an average of 10 replicates and each experiment was repeated at least thrice. * = Highest response

Phellodendron amurense Rupr (Azad et al. 2005), Amorphophallus albus ( $\mathrm{Hu}$ and $\mathrm{Li}$ 2008), G entiana spp (Fiuk and Rybczynski 2008).

In this investigation, callus derived shoots were isolated and cultured in different concentrations of IBA (0.1-2.5 $\left.\mathrm{mgl}^{-1}\right)$ for root induction . The highest percentage of root induction was $80.42 \%$ on the half strength MS medium consisting of $1.0 \mathrm{mgl}^{-1}$ IBA followed by $63.64 \%$ on the medium having $0.5 \mathrm{mgl}^{-1}$ IBA. The highest number of roots per shoot was 4.0 in the MS medium having $1.0 \mathrm{mgl}^{-1}$ IBA (Table III; Fig. E) followed by 3.0 in the MS medium having $0.5 \mathrm{mgl}^{-1}$ IBA. On the left hand, the lowest percentage of root induction was $10.45 \%$ in the medium having $2.5 \mathrm{mgl}^{-1}$ IBA and the lowest number of root induction was $10.45 \%$ in the medium having $2.5 \mathrm{mgl}^{-1}$ IBA and the lowest number of root induction was 1.0 in the medium having $2.5 \mathrm{mgl}^{-1}$ IBA. Thus, half strength
Table III: Effect of IBA in half-strength MS medium on root induction in regenerated shoots.

\begin{tabular}{c|c|c|c}
\hline $\begin{array}{l}\text { IBA } \\
\left(\mathrm{mgl}^{-1}\right)\end{array}$ & $\begin{array}{c}\text { Root } \\
\text { induction (\%) }\end{array}$ & $\begin{array}{c}\text { Number of } \\
\text { roots/shoot } \\
(\mathrm{M} \pm \mathrm{SE})\end{array}$ & $\begin{array}{c}\text { Root length } \\
(\mathrm{cm}) \\
(\mathrm{M} \pm \mathrm{SE})\end{array}$ \\
\hline 0.1 & 40.37 & $1.8 \pm 0.8$ & $1.6 \pm 0.3$ \\
0.5 & 63.64 & $3.0 \pm 0.9$ & $2.7 \pm 0.9$ \\
1.0 & $80.42^{*}$ & $4.0 \pm 1.0$ & $3.5 \pm 0.5$ \\
1.5 & 30.24 & $2.0 \pm 0.7$ & $2.4 \pm 0.4$ \\
2.0 & 20.35 & $2.5 \pm 0.5$ & $1.3 \pm 0.6$ \\
2.5 & 10.45 & $1.0 \pm 0.8$ & $0.8 \pm 0.7$ \\
\hline
\end{tabular}

Note : Each value represents an average of 10 replicates and each experiment was repeated at least thrice. $*=$ Highest response.

MS medium supplemented with $1.0 \mathrm{mgl}^{-1}$ IBA was found to be an ideal treatment for root induction (Fig. E). Many other workers reported similar results for root induction in various types of plants, namely Carica papaya (Islam et al. 2000), Ocimum basilicum (Sahoo et al. 1997), Gymnema sylvestre (Komalavalli and Rao 2000), Tylophora indica (Faisal et al. 2007).

After 30 days, well rooted plantlets were achieved. Subsequently, the plantlets were removed from agar medium and planted in small pots containing sterile sand, soil and humus in the ration of 1:2:2 (Fig. F). The potted plantlets were covered by transparent polythene sheet to maintain high humidity and within 15-20 days new leaves were emerged from the plantlets that resumed new growth. After 50-55 days, the plants were transplanted in the field condition, where $80 \%$ plants were survived and grown satisfactory.

\section{Acknowledgements}

The authors are gratefuly to the Department of Genetic Engineering and Biotechnology, University of Rajshahi, Bangladesh for providing financial support and laboratory facilities to carry out this investigation. 


\section{References}

Ajithkumar D. and Seeni S. (1998) Rapid clonal multiplication through in vitro axillary shoot proliferation of Aegle marmelos (L.) Corr. A medicinal tree. Plant Cell Rep. 17: 422-426.

Arul V., Miyazaki S. and Dhananjayan R. (2005) Studies on the anti-inflammatory, antipyretic and analgesic properties of the leaves of Aegle marmelos Corr. J. Ethnopharmacol. 96(1-2): 159-163.

Arumugam S. and Rao M. V. (1996) In vitro production of plantlets from cotyledonary node cultures of Aegle marmelos (L.) Corr. Adv. Plant Sci. 9 (2): 181-186.

Arya H. C., Ramawat K. G. and Suthar K. C. (1981) Culture and differentiation of plants of economic importance Aegle Marmelos L. J. Indian Bot. Soc. 60: 134-137.

Azad M. A. K., Yokota S., Ohkubo T., Andoh Y., Yahara S. and Yoshizawa N. (2005) In vitro regeneration of the medical woody plant Phellodendron amurense Rupr. through excised leaves. Plant Cell Tiss. Organ. Cult. 80(1) : 43-50.

Beena M. R. and Martin K. P. (2003) In vtro propagation of the rare medicinal plant Ceropegia candelabrum L. through somatic embryogenesis. In Vitro Cell. Dev. Biol. Plant. 39: 510-513.

Bhati R., Shekhawat N. S. and Arya H. C. (1992) In vitro regeneration of plantlets from root segments of Aegle marmelos. Indian J. Exp. biol. 30: 844-845.

Faisal M., Ahmad N. and Anis M. (2007) An efficient micropropagation system for Tylophora indica: an endangered, medicinally important plant. Plant Biotechnology Reports. 1(3): 155-161.

Fiuk A. and Rybczynski J. J (2008) Genotype and plant growth regulator-dependent response of somatic embryogenesis from $G$ entiana spp. leaf explants. In Vitro Cell. Dev. Biol Plant. 44(2): 90-99.
Hu J. and Li J. (2008) Morphogenetic pathway in petiole derived callus of Amorphophallus albus in vitro. Acta Physiologiae Plantarum. 30 (3): 389-393.

Islam M., Islam R., Hossain M., Alam M. F. and Banu N. A (2000) Callus Induction and Plant Regeneration from Immature Zygotic Embryos of Carica papaya L. Bangladesh J. Genet. Biotech. 1(1): 123-128.

Jauhari O. S., Singh R. D. and Awasthi R. K. (1969) Survey of some important varieties of Bael (Aegle marmelos Correa). Punjab Hort. J. 9: 48.

Kala C. P. (2006) Ethnobotany and ethnoconservation of Aegle marmelos (L) Correa. Indian Journal of Traditional Knowledge. 5(4): 541-550.

Kirtikar K. R and Basu S. D. (1935) Indian Medicinal Plants. Vol. III. (Lalit Mohan Basu, Allahabad, India). pp. 119-120.

Komalavalli N. and Rao M. V. (2000) In vitro micropropagation of Gymnema sylvestre- A multipurpose medicinal plant. Plant cell Tiss. Organ. Cult. 61(2): 97-105.

Mazumder R., Bhattacharya S., Mazumdrer A., Pattnaik A. K., Tiwary P. M. and Chaudhary S. (2006) Antidiarrhoeal evaluation of Aegle marmelos (Correa) Linn. root extract. Phytother Res. 20 (1): 82-84.

Morton J. (1987) Bael Fruit. In: Fruits of warm climates. (Julia F. Morton, Miami. FL) pp. 187-190.

Murashige T. and Skoog F. (1962) A revised medium for rapid growth and bioassay with tobacco tissue culture, Physiol. Plant 15: 473-497.

Narendhirakannan R. T., Subramanian S. and Kandaswamy M. (2005) Mineral content of some medicinal plants used in the treatment of diabetes mellitus. Biol. Trace Elem. Res. 103(2): 109-115.

Paricha S. (2004) Bael (Aegle Marmelos) Nature's Most Natural Medicinal Fruit. (Orissa Review). p. 156. 
Purohit S. S. and Vyas, S. P. (2005) Medicinal Plant Cultivation-A Scientific Approach. (Agrobion. India) pp. 282

Quraishi A., Koche V., Sharma and P. Mishra S. K. (2004) In vitro Clonal Propagation of Neem (Azadriachta indica). Plant Cell Tiss. Organ. Cult 78 (3) 281-284.

Sahoo Y,. Pattnaik S. K. and Chand P. K. (1997) In vitro clonal propagation of an aromatic medicinal herb Ocimum basilicum L. (sweet basil) by axillary shoots proliferation . In vitro Cell. Dev. Biol. Plant. 33(4): 293-296.
Singh N. K. and Sehgal C. B (1999) Micropropagation of Holy Basil (Ocimum sanctum Linn). form young inflorescences of mature plants Plant Growth Regulation 29: $161-166$

Singh R. N. and Roy S. K. (1984) The Bael cultivation and processing. (I.C.A.R, New Delhi), p.54

Watt G. (1889) A Dictionary of the Economic Products of India. (I. Cosmo Publicatio, Delhi) pp.90-92.

Received : September 07, 2008;

Accepted : February 11, 2009 